\title{
The genesis of volcanic risk assessment for the Auckland engineering lifelines project: 1996-2000
}

\author{
Michele Daly ${ }^{*}$ and David Johnston
}

\begin{abstract}
The Auckland Engineering Lifelines Project (A.E.L.P.) was initiated by the Auckland Regional Council, New Zealand, in 1996 to reduce the damage to and downtime of utilities such as water, wastewater, gas, power, etc., resulting from a variety of natural and technological hazards. A key initial project was a volcanic risk assessment. This paper describes the methodology that was developed to specifically assess the volcanic risk to lifelines from the Auckland Volcanic Field and distal volcanic centres in the central North Island, the application of the risk assessment and further developments beyond the initial project.
\end{abstract}

Keywords: Volcanic risk assessment; Lifeline utilities; Auckland; Lifeline interdependencies

\section{Background}

The Auckland Engineering Lifelines Project (A.E.L.P.) was initiated by the Auckland Regional Council, New Zealand, in 1996 and involved some 40 organisations comprising local government, utility service providers, and other interest groups. The aim of the A.E.L.P. was to reduce the damage to and downtime of utilities such as water, wastewater, gas, power, etc., resulting from a variety of natural and technological hazards. The project assessed the vulnerability of utilities, identified interdependencies and developed practical strategies for reducing risk, and for response and reinstatement following a hazard event. The design of the project was initially based on and followed from two other successful Engineering Lifelines Projects in New Zealand; the Wellington Earthquake Lifelines Study (Hopkins et al. 1993) and the Christchurch Engineering Lifelines Study (Centre for Advanced Engineering, 1997).

The A.E.L.P. adopted an "all hazards approach" and in the hazard identification stage of the project discussion documents were prepared for a number of hazards including earthquake, tsunami, cyclone, drought, fire, hazardous substances spills, biohazards, vandalism, and volcanic eruptions from the Auckland Volcanic Field as well as from the more distal volcanoes in the central North Island (Daly and Wilkie, 1997). For the final study, these hazards were reduced to earthquake, volcano, tsunami and cyclone. A key outcome of the project, and an important deliverable,

* Correspondence: m.daly@gns.cri.nz

GNS Science Ltd, PO Box 30368, Lower Hutt 5040, New Zealand was to enable participating organisations to identify the extent of their interdependence on other lifeline services. The identification of interdependencies not only allows the individual organisations to better prepare themselves for disaster, but also enables them to influence and prioritise the response of other organisations to them immediately after a disaster event.

At the time of the establishment of the A.E.L.P., there was only rudimentary information available about the Auckland Volcanic Field. The Ministry of Civil Defence had produced the Volcanic Hazard Information Series, translating available scientific knowledge into a publicly accessible form (Smith \& Allen, 1993). The hazard analyses produced for the A.E.L.P. (Daly and Wilkie, 1997) were based on this information, as well as a few specifically commissioned studies for earthquake hazards (liquefaction, ground shaking, landslides), ex-tropical cyclone and tsunami. In the case of volcanic hazards, work was commissioned by the Auckland Regional Council to bring together the available information and extend this into hazard and risk commentaries that could then be adapted for use in the A.E.L.P. (Johnston et al. 1997a, b). This early work prompted local authorities to start to take the possibility of another eruption from the Auckland Volcanic Field more seriously and a long term commitment to expanding a monitoring network established by the University of Auckland was made. No systematic risk assessment had been undertaken up to this point. 
This paper describes the methodology that was developed to specifically assess the volcanic risk from the Auckland Volcanic Field and distal centres in the central North Island for use in the A.E.L.P. This methodology is important in a historical context because since 2000 a number of initiatives have been established to improve Auckland's understanding and management of its volcanic risk e.g. the Auckland Lifelines Group (ALG), the Volcanic Impacts Study Group (VISG), the Auckland Volcanic Science Advisory Group (AVSAG), the Auckland Volcanic Contingency Plan and the multi-organisational research programme DEVORA (Determining Volcanic Risk in Auckland). The early risk assessment methodology developed for the A.E.L.P. set the groundwork for these subsequent efforts. A similar methodology used to assess the earthquake risk for Auckland for use in the A.E.L.P project has been previously described in Wilkie and Daly, (1998).

\section{Volcanic hazards in Auckland}

The city of Auckland is built on a basaltic volcanic field (Figure 1) which may have been active as recent as $1400 \mathrm{~A}$. D. (Sandri et al. 2012). The Auckland Volcanic Field covers $360 \mathrm{~km}^{2}$ and contains 50 identified vents. Twenty eruptions have occurred over the past 20000 years with Rangitoto the largest and youngest having formed about 600 years ago. Eruptive styles from the Auckland Volcanic Field range from episodes of Strombolian and/or Hawaiian fire fountaining commonly accompanied by phreatomagmatic episodes with a Volcanic Explosivity Index (VEI) between 0 and 2 . Principle hazards include tephra falls, lava flows, ballistics, and pyroclastic density currents (Sandri et al. 2012).

However, the Auckland Region faces an additional volcanic threat from several large central North Island volcanic centres (Figure 2) that are located 140-280 km to the south and south-east. In the central North Island there are two major volcano types: (i) andesitic cones and (ii) rhyolitic calderas (Wilson et al. 1995). Activity at cone volcanoes (i.e. Mt Taranaki; and Tongariro, Ngauruhoe, and Ruapehu (the last three collectively comprising the Tongariro Volcanic Centre)) are typically characterised by a succession of small to moderate sized eruptions occurring, on average, every 50 to 300 years from approximately the same vent area over a long period of time. Activity at caldera volcanoes, on the other hand (i.e. Taupo, Okataina and Mayor Island), is characterised by far less frequent (on average every 1000-2000 years), moderate to exceptionally large sized eruptions. These eruptions are capable of generating large volumes of material that can be distributed over exceptionally large areas many hundreds of kilometres downwind. The impact of a distant eruption will be uniformly widespread across the entire Auckland Region (Johnston et al. 1997a) and contrasts with the relatively localised impact of hazards generated from an eruption within the Auckland Volcanic Field (Johnston et al. 1997b).

\section{A.E.L.P. methodology overview}

The general methodology used for the A.E.L.P. can be broken up into a number of tasks as shown in the flow chart in Figure 3. Definitions of terms used in Figure 3 (and throughout the text) are shown in Table 1. The focus of the A.E.L.P. was on utility impact and utility response to make the project manageable. Second order impacts including those on the wider community were to be considered as part of Stage 2 (Figure 3). At the time of writing (mid-2014), Stage 2 was almost complete.

Task 3 in Figure 3 identified the vulnerabilities or sensitivities of each utility's distribution networks and critical facilities ('networks' and 'nodes') to damage using the information from Tasks 1 and 2. Work undertaken in Task 2 produced an important advancement in the ability to move from hazard to damage through the translation of descriptive (qualitative) hazard impacts into a form that the utilities could use to assess impacts to specific infrastructural components (e.g. pipes, electricity sub-stations, water pumping stations, roads etc.). Being able to assess impacts in this way provided a first step towards an assessment of risk which would be expanded upon in subsequent work (e.g. DEVORA, 2014).

The Task 3 analysis was split into:

i. A uniform hazard analysis, which analysed the vulnerability of each individual utility to the hazards based on known information, and

ii. A scenario hazard event, which analysed the vulnerability of all utilities to a clearly defined hypothetical event exemplifying the most likely worst case for each hazard.

The uniform hazard analysis examined information known about each hazard across the entire region in order to highlight to each utility specific areas where its networks and nodes might be vulnerable to the impacts of a hazard event wherever the event occurred.

The focus of the scenario events was not to identify the vulnerability of specific strategic assets but rather to look at the response of the network system as a whole and show the interdependencies between individual utilities by using a particular eruption scenario as an example.

Utilities were asked to step through a vulnerability assessment (Tasks 3 and 4 in Figure 3) for each of the uniform and scenario hazards provided, with the assistance of flow charts and matrices describing damage probability and type (Figures 4, 5, 6 and Tables 2 and 3).

Utilities were then asked to identify their likely response to the event (Task 9 in Figure 3) and their ability to recover (repair identified network and node 


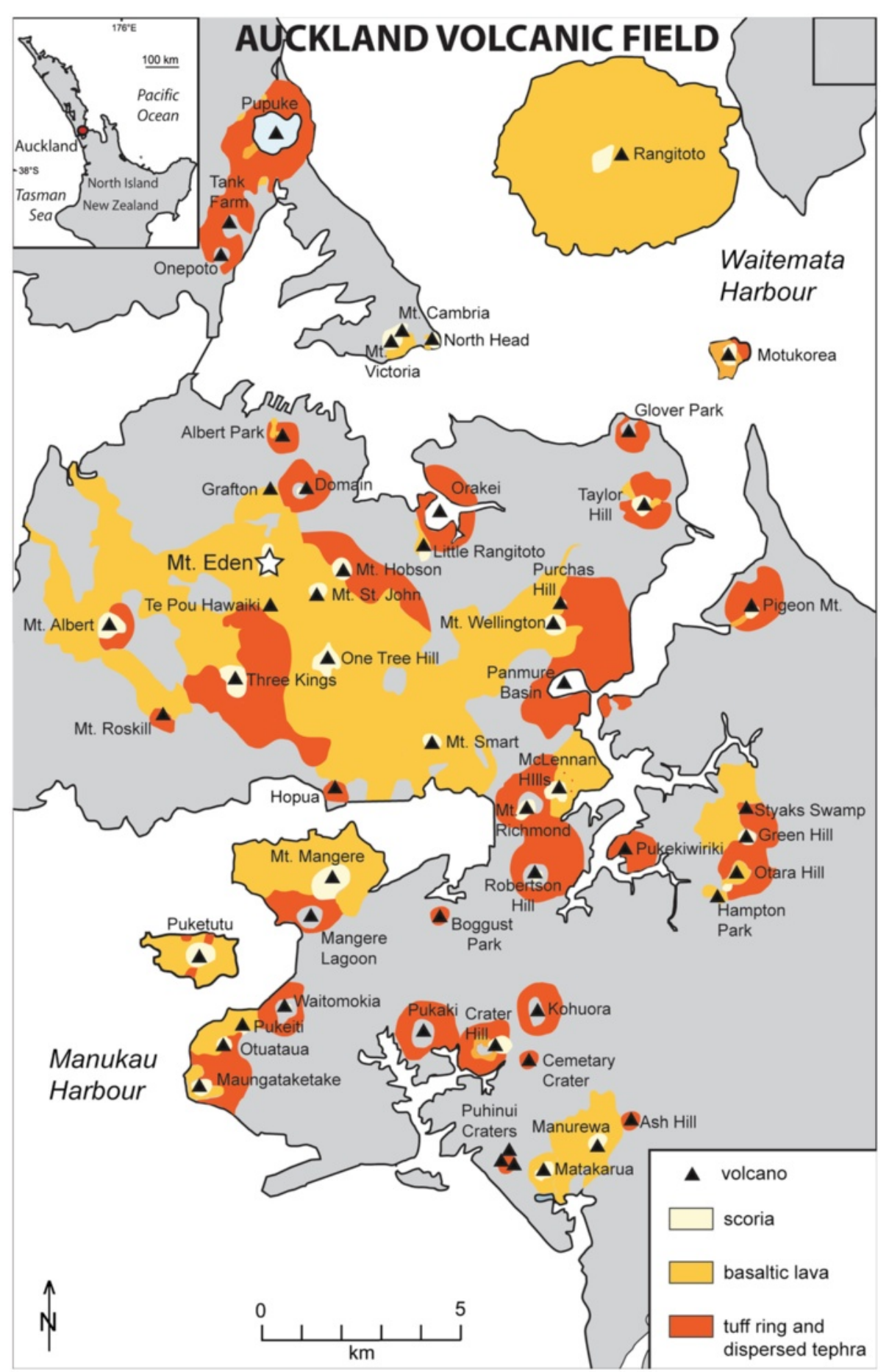

Figure 1 Map of the Auckland Volcanic Field. (source: Lindsay et al. 2011).

elements) and restore service. A 'recovery profile' for each utility was developed which when combined with other recovery profiles allowed for an analysis of the utility system impact (Task 6 in Figure 3).

Finally, utilities were asked as part of Task 3 (Figure 3) to develop a prioritised mitigation list with help from matrices specifically developed for this purpose (Table 4).

The A.E.L.P. methodology used hazard and infrastructure maps developed in ARC GIS (ARC Geographical Information Systems). Damage probability and damage type matrices were developed by the project team, and 


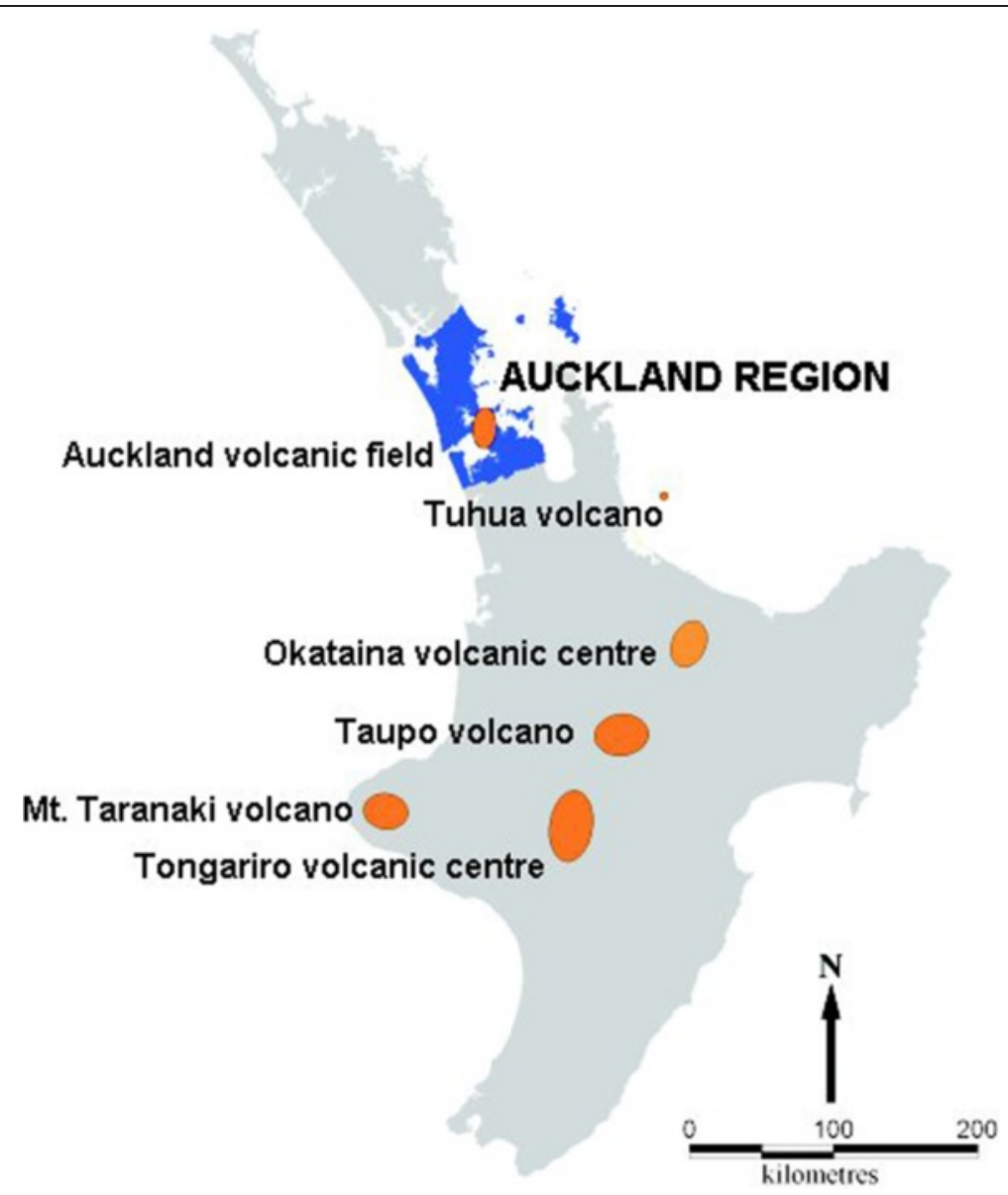

Figure 2 Map showing the North Island of New Zealand, the location of the Auckland region (blue), and the volcanic centres identified as posing a risk to the region. (source: Magill 2002).

the vulnerability, recovery and interdependency analyses were conducted in workshop settings. While much of the analysis could have been automated, the educational value of the discussions was enormous and resulted in much higher levels of buy-in to the eventual mitigation work that was recommended in the concluding stages of the project and which formed the basis for subsequent work undertaken by the lifeline utilities as part of the Auckland Lifelines Group.

\section{Volcanic hazard analysis}

The volcanic hazard analysis looked at the effects of an eruption in the Auckland Volcanic Field (Figure 1) as well as an eruption elsewhere in the North Island (Figure 2), as distal eruptions have the potential to deposit ash in such volumes as to have a major disruptive impact on the region's utility services and wider community.

For the Auckland Volcanic Field, the assessment is complicated by the fact that the next eruption could occur anywhere within a $360 \mathrm{~km}^{2}$ area. A zone of uniform hazard was identified which comprised the known extent of the volcanic field. The focus of the uniform hazard was to identify the vulnerability of each utility's service network and nodes to an event, which could occur anywhere within the Auckland Volcanic Field.

Three scenarios events were used in the project. One local scenario from the Auckland Volcanic Field centred in the waterfront of the central business district (CBD) and two distant eruptions from Mt Taranaki and the Okataina Volcanic Centre (Figure 2) (based on scenarios developed by Johnston et al. 1997a and 1997b). The local scenario event has an average return period of 1:1,000 years, based on the last 20 such events occurring over a 20,000 year period. Return periods for Mt Taranaki and Okataina were taken as 1:300 and 1:2,000 years respectively (Johnston et al.1997a and 1997b).

The CBD location was selected for the local event because it encompassed both phreatomagmatic (explosive) and magmatic (effusive) eruption styles and because it 


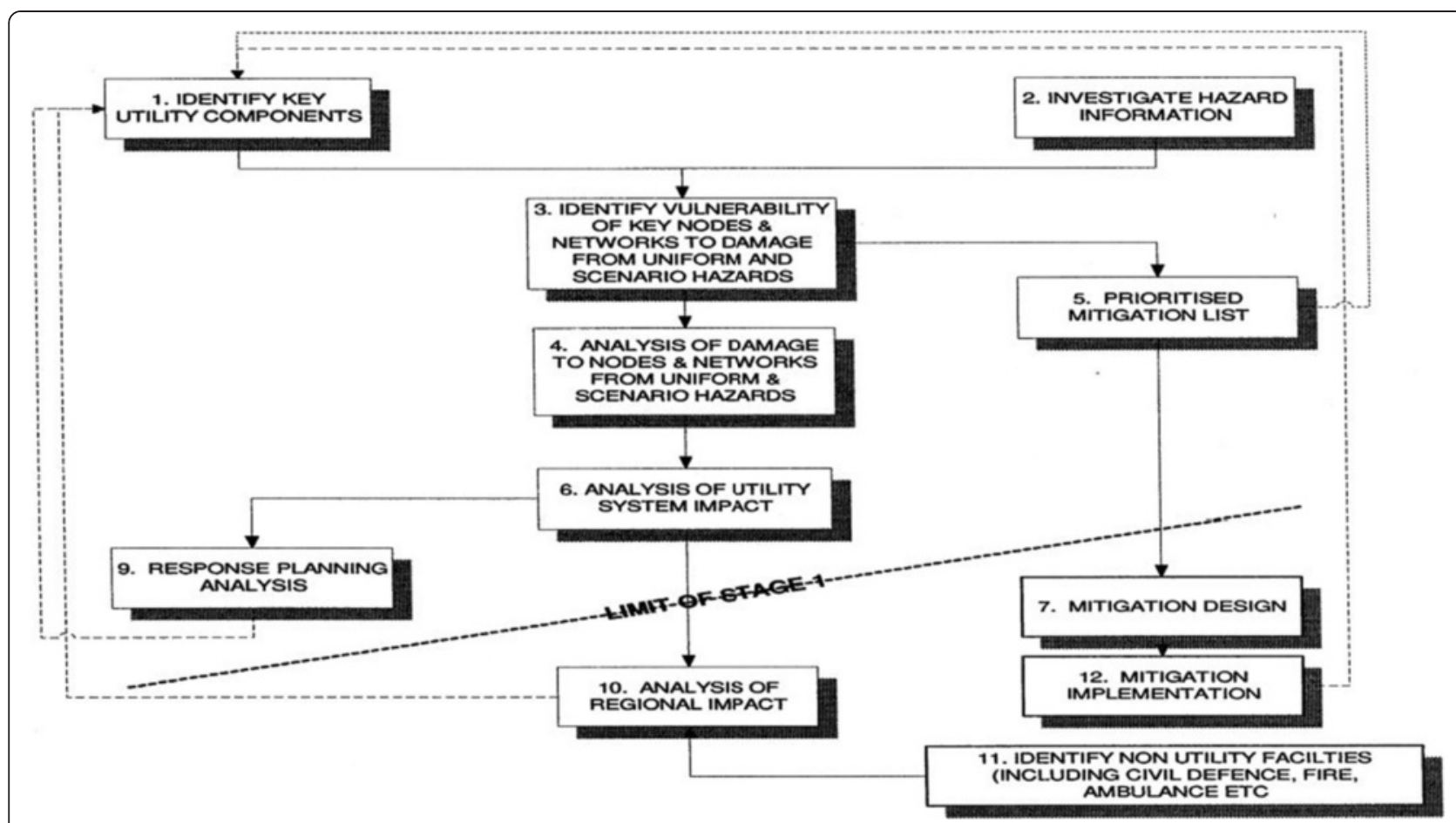

Figure 3 Flow chart of the A.E.L.P. methodology. (source: Daly and Wilkie 1999).

affected the central business district, rail and port services as well as residential areas (Figure 7).

The eruption style and magnitude of the eruption scenario was based on a Mt. Wellington (Figure 1) sized eruption in terms of the volume of material erupted. For the purposes of the A.E.L.P, this size eruption was assumed to totally destroy above ground services within a $3 \mathrm{~km}$ radius of the vent (blast zone). Below ground services were assumed to be affected within a $1 \mathrm{~km}$ radius of the vent. In order to ensure full service redundancy, a

Table 1 Definition of terms used in the Auckland Engineering Lifelines Project 1996-1999 (modified after Daly and Wilkie 1999)

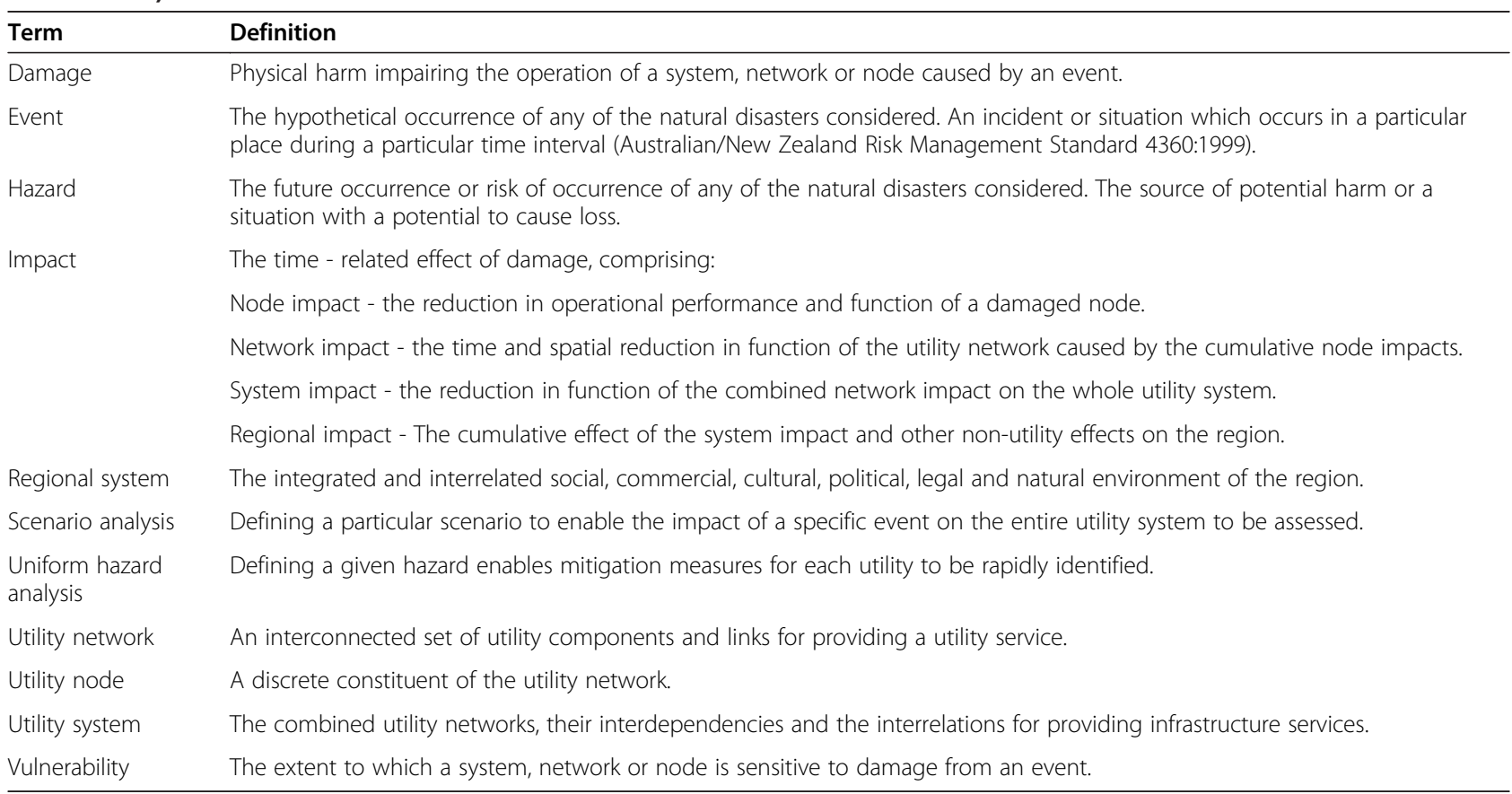




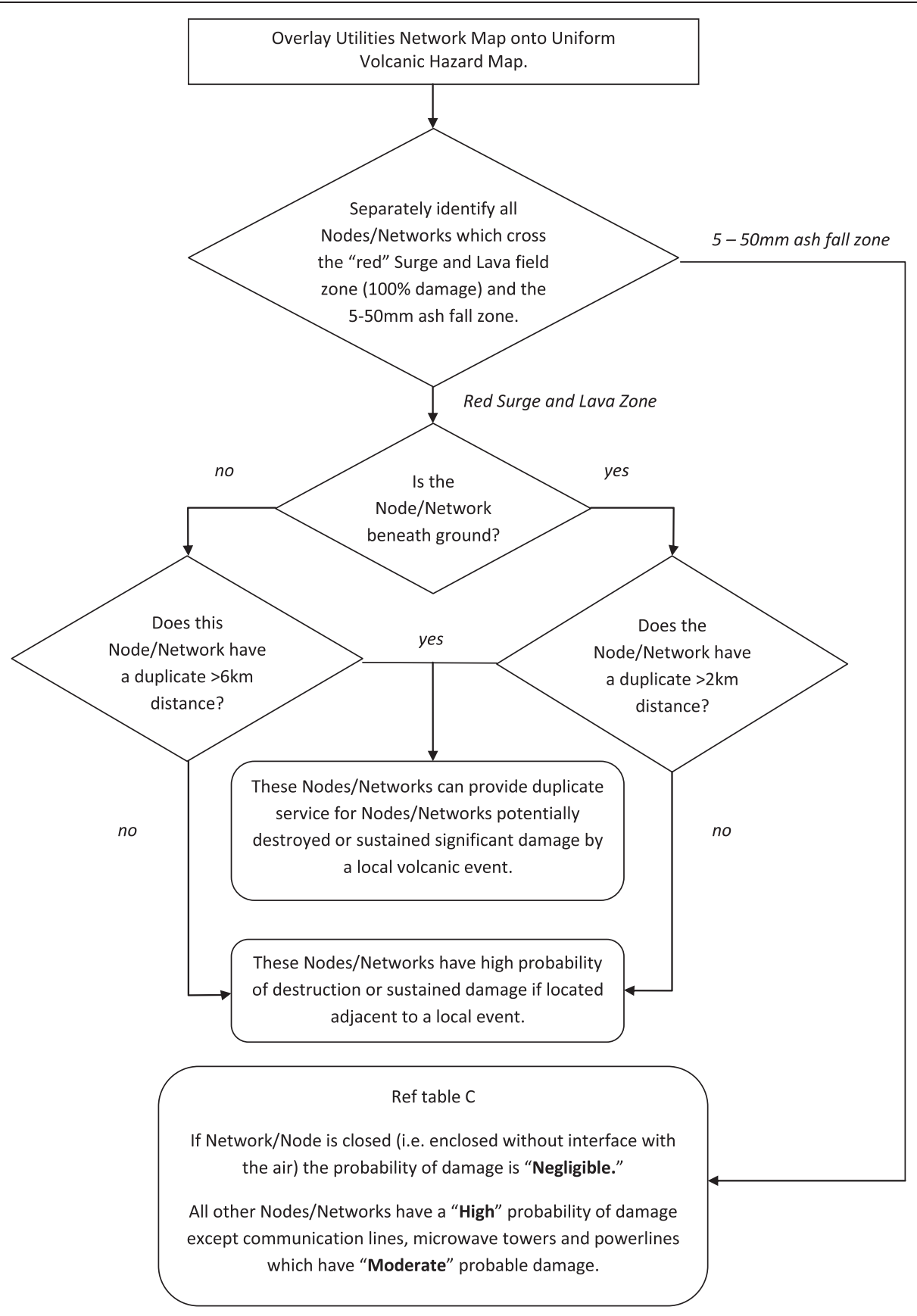

Figure 4 Flow chart for damage assessment of nodes and networks due to uniform volcanic hazard. (source: Daly and Wilkie 1999).

$6 \mathrm{~km}$ separation (or $2 \mathrm{~km}$ separation for services below ground) would be needed between the utility elements. The lifeline utilities examined their own vulnerabilities on this basis. However, because the main effects of the distant eruptions were from ash fall, most of the vulnerability assessments focused on the effects of ash fall rather than complete localised destruction of part of the utility network.

The above ground damage zone of $3 \mathrm{~km}$ radius was subsequently adopted by the Auckland Regional Council in their volcanic contingency plan. The Council added a further $2 \mathrm{~km}$ margin of safety to create a $5 \mathrm{~km}$ radius for evacuation purposes (Auckland Regional Council, 2002). At the time of writing, the renamed $3 \mathrm{~km}$ 'extreme risk zone' and the additional $2 \mathrm{~km}$ 'high risk zone' remain as the starting point for evacuation planning purposes (Auckland Council, 2013).

The two distant eruption scenarios focussed on ash as the primary hazard. The first deposited $1 \mathrm{~mm}$ of volcanic ash over the region from a $0.1 \mathrm{~km}^{3}$ andesitic 


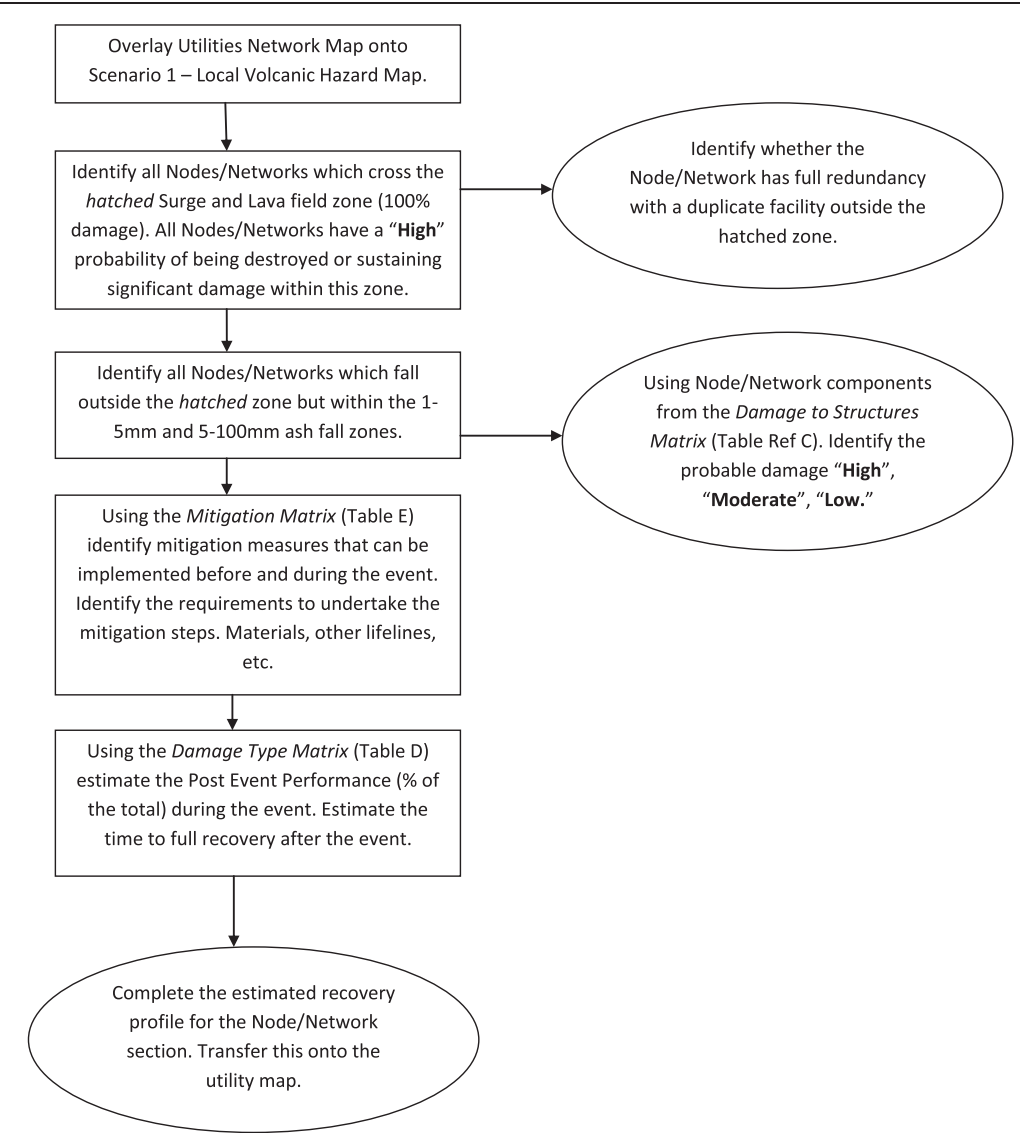

Figure 5 Flow chart for damage assessment of nodes and networks due to local volcanic hazard scenario. (source: Daly and Wilkie 1999). Note that references to Tables C, D and E in this flow chart are Tables 2, 3 and 4 in this paper respectively.

eruption of Taranaki (Figure 2) and the second deposited $100 \mathrm{~mm}$ of volcanic ash from a $4 \mathrm{~km}^{3}$ rhyolite eruption from the Okataina Volcanic Centre (Figure 2).

\section{Damage and mitigation assessment methodology}

Two matrices were developed and provided a qualitative assessment of the type and likelihood of damage (Tables 2 and 3) from ash fall to a range of infrastructure within the Auckland region. These matrices are based on observed impacts of past volcanic eruptions (e.g. Blong 1984, Johnston 1997a). A third matrix provided options for mitigating the effects of ash fall (Table 4). As mentioned above, these matrices produced an important advancement in the ability to move from hazard to volcanic risk through the translation of descriptive (qualitative) hazard impacts into a form that the utilities could use to assess impacts to specific infrastructural components (e.g. pipes, electricity sub-stations, water pumping stations, roads etc.). This early work has led to and informed the subsequent development of semi-quantitative descriptions of damage (e.g. Wilson et al. 2009), posters for utilities on how to manage volcanic ash (Wilson et al. 2014b) and fragility functions for different infrastructural components to volcanic ash (e.g. Wardman et al., 2012; Wilson et al., 2012; Wilson et al. 2014a).

\section{Damage assessment of nodes and networks due to uniform volcanic activity}

A zone of uniform hazard was identified which comprised the known extent of the volcanic field (Figure 8). Within this zone, an eruption was assumed to cause $100 \%$ damage to over-ground services within a $3 \mathrm{~km}$ radius (blast zone) and to underground services within a radius of $1 \mathrm{~km}$. Outside these distances, the principal damage results from ash. The analysis damage to nodes and networks due to uniform volcanic activity was undertaken following the flow chart in Figure 4. The uniform hazard analysis is essentially a rapid once over of all critical network facilities which ranks them as having negligible, moderate, or high probability of damage based on their overall damage assessment. This enabled a prioritised list of mitigation measures to be developed which was able to be incorporated directly into utilities' own strategic asset management and maintenance programmes. 


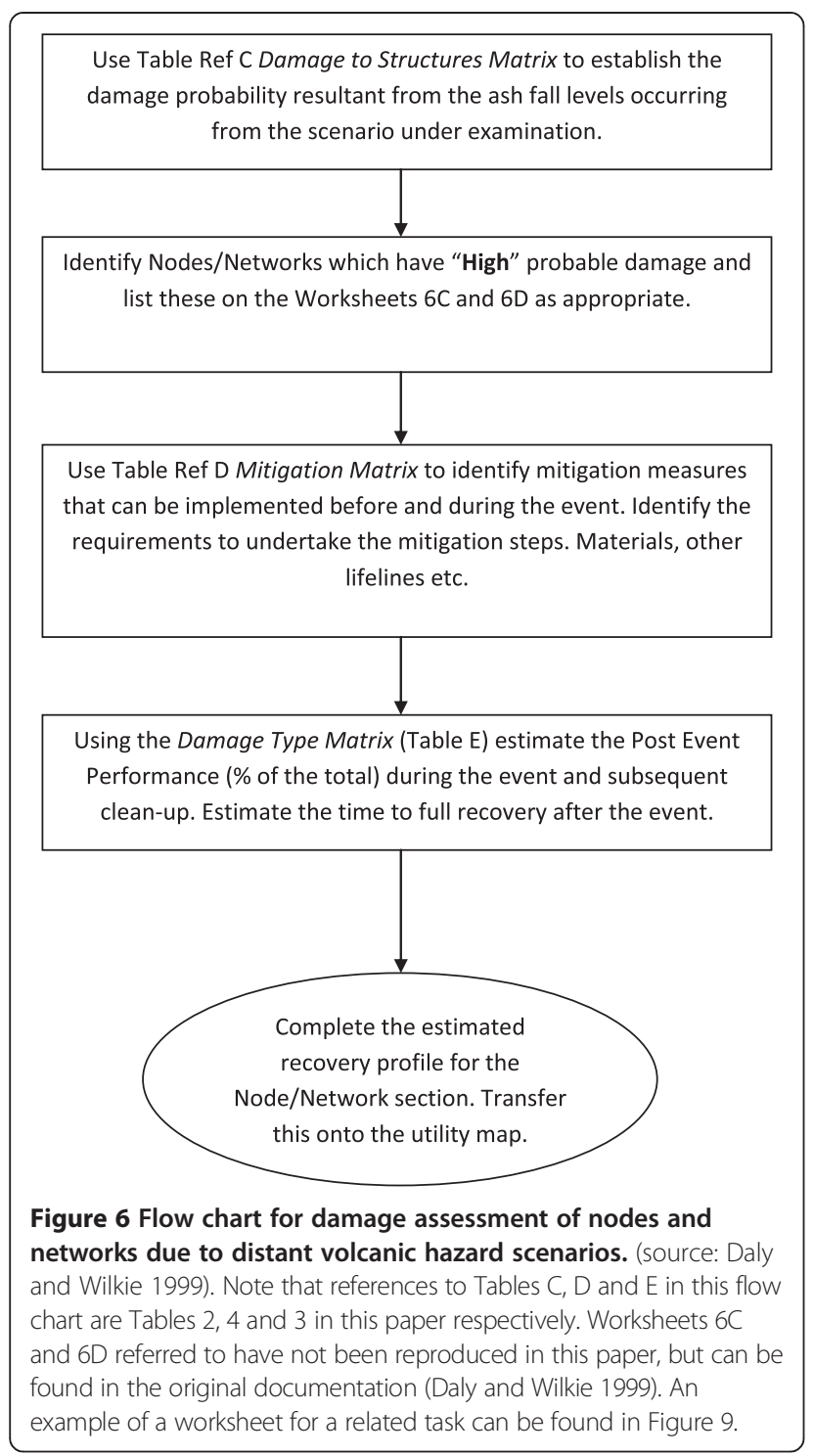

\section{Damage assessment of nodes due to local and distant scenario volcanic eruptions}

The analysis of damage to nodes and networks due to the local scenario eruption was undertaken following the flowchart in Figure 5, on worksheets as shown in Figure 9.

Similarly, the analysis of damage to nodes and networks due to the different ash thicknesses from the two distal eruption scenarios was undertaken following the flowchart in Figure 6, on worksheets similar to that shown in Figure 9.

Through consideration of the likely damage from a particular scenario a picture can be developed of the effects of an event on the entire system and forms a resource for use when developing strategies for response and recovery. Interdependence is addressed through reconciling the impacts of various services from the same event with performance post event.

\section{Recovery profile (interdependencies)}

The concept of a Recovery Profile was developed to describe how a hazard event would affect a utility's ability to function at different stages after a scenario event by asking:

a) What percentage of service was available immediately after the event?

b) What percentage of service was available one week after the event?

c) How many days, weeks or months would be required to get back to full service, including any temporary fixes?

Lifelines were asked to develop a recovery profile per significant network node or element (Figure 9) and ultimately to form a view of the overall recovery profile of their network as a result.

An iterative process was used, initially assuming unlimited resources and unrestricted access to sites for repairs. The recovery profiles of all lifelines were discussed in a workshop setting and reviewed. Individual utilities then reassessed their profiles on the basis of a more realistic assessment of access, competition for resources and interdependency of services. Subsequent discussions with other lifelines utilities typically, and as expected, had the effect of making recovery profiles longer.

The methodology initially proposed to map the recovery profiles to show impacted zones, i.e. areas where service was unavailable one day and one week after the event, and where full recovery took a long time. In practice this proved impractical within the timeframe due to the collation of large volume of data from the recovery profiles that this exercise required. As a result, the exercise was amended to focus on areas or elements of significant service loss in each utility and how that affected the rest of that network.

A workshop was held at the conclusion of the vulnerability assessment to allow each lifeline utility to:

a) Outline its network's capabilities for servicing the other utilities,

b) Hold individual discussions with each of the other lifeline sectors to identify and understand each other's interdependencies.

A matrix for the scenario eruption (Figure 10) was developed which demonstrated the interdependencies and the priority which each lifeline had on the others for operation and recovery. As network systems are often complex, no particular precision can be claimed in the numbers given, 
Table 2 Volcanic ash-induced damage to structures matrix (modified after Daly and Wilkie, 1999)

\begin{tabular}{|c|c|c|c|c|}
\hline Structure & Ash thickness $<1 \mathrm{~mm}$ & Ash thickness $1-5 \mathrm{~mm}$ & Ash thickness $5-100 \mathrm{~mm}$ & Ash thickness $>100 \mathrm{~mm}$ \\
\hline \multicolumn{5}{|l|}{ Pipework } \\
\hline Open systems (ie stormwater) & Low probability & High probability & High probability & High probability \\
\hline Closed systems & Negligible & Negligible & Negligible & Negligible \\
\hline \multicolumn{5}{|l|}{ Building structures } \\
\hline Flat-roof & Low probability & Mod. probability & High probability & High probability \\
\hline Pitched-roofs $\left(>20^{\circ}\right)$ & Low probability & Mod. probability & High probability & High probability \\
\hline \multicolumn{5}{|l|}{ Building services } \\
\hline Air-conditioning & Low probability & Mod. probability & High probability & High probability \\
\hline Gutters & Low probability & Mod. probability & High probability & High probability \\
\hline \multicolumn{5}{|l|}{ Electricity services } \\
\hline Power lines & Negligible & Low probability & Mod. probability & High probability \\
\hline \multicolumn{5}{|l|}{ Power line insulators: } \\
\hline Low voltage & Negligible & Mod. probability & High probability & High probability \\
\hline High voltage & Negligible & Low probability & Mod. probability & High probability \\
\hline Substations & Negligible & Mod. probability & High probability & High probability \\
\hline \multicolumn{5}{|l|}{ Civil structures } \\
\hline Roads & Low probability & High probability & High probability & High probability \\
\hline Rail & Negligible & Mod. probability & High probability & High probability \\
\hline \multicolumn{5}{|l|}{ Wastewater } \\
\hline Sewage pumps & Low probability & High probability & High probability & High probability \\
\hline Sewage treatment plant & Low probability & Mod. probability & High probability & High probability \\
\hline \multicolumn{5}{|l|}{ Water Supply Systems } \\
\hline River/Stream & Low probability & High probability & High probability & High probability \\
\hline Uncovered reservoir & Low probability & Mod. probability & High probability & High probability \\
\hline Cover reservoir/ground water & Negligible & Negligible & Negligible & Negligible \\
\hline Roof-fed tank & Low probability & High probability & High probability & High probability \\
\hline \multicolumn{5}{|l|}{ Telecommunications } \\
\hline Lines & Negligible & Low probability & Mod. probability & High probability \\
\hline Microwave towers & Low probability & Mod. probability & Mod. probability & High probability \\
\hline \multicolumn{5}{|l|}{ Exchange equipment: } \\
\hline External air-conditioning & Low probability & High probability & High probability & High probability \\
\hline Internal Air-conditioning & Negligible & Low probability & Low probability & Low probability \\
\hline \multicolumn{5}{|l|}{ Specific infrastructure } \\
\hline Ports & Low probability & High probability & High probability & High probability \\
\hline Airports: Air transport & Mod. probability & High probability & High probability & High probability \\
\hline
\end{tabular}

but the table highlights the links between lifelines in the period following an eruption affecting Auckland. The process showed that road (access), cellular communication, and fuel, were lifelines on which others were hugely reliant. A close fourth was electricity. Note that water supply was ranked quite low in the analysis. This was because the project focussed on the physical recovery needs of the lifelines themselves rather than on the immediate needs of staff or the community.

\section{Results and discussion}

Analysis of the worksheets, workshop discussion summaries, and Figure 10 confirms many of the conclusions reached in other studies (e.g. Johnston 1997a):

a) Specific items of equipment identified as critical to a network's operation and which are also highly vulnerable to volcanic ash, should be protected (if possible) against ash fall. 
Table 3 Volcanic ash-induced damage type matrix (source: Daly and Wilkie, 1999)

\begin{tabular}{|c|c|c|c|c|}
\hline Structure & Ash thickness $<1 \mathrm{~mm}$ & Ash thickness $1-5 \mathrm{~mm}$ & Ash thickness $5-100 \mathrm{~mm}$ & Ash thickness $>100 \mathrm{~mm}$ \\
\hline \multicolumn{5}{|l|}{ Pipework } \\
\hline $\begin{array}{l}\text { Open systems } \\
\text { (ie stormwater) }\end{array}$ & $\begin{array}{l}\text { Blockage depending on } \\
\text { water (or sewage turbidity) }\end{array}$ & $\begin{array}{l}\text { Blockage depending on } \\
\text { water (or sewage turbidity) }\end{array}$ & $\begin{array}{l}\text { Blockage depending on } \\
\text { water (or sewage turbidity) }\end{array}$ & $\begin{array}{l}\text { Blockage depending on water } \\
\text { (or sewage turbidity) }\end{array}$ \\
\hline Closed systems & $\mathrm{N} / \mathrm{A}$ & $\mathrm{N} / \mathrm{A}$ & $\mathrm{N} / \mathrm{A}$ & $\mathrm{N} / \mathrm{A}$ \\
\hline \multicolumn{5}{|l|}{ Building structures } \\
\hline Flat-roof & $\begin{array}{l}\text { Corrosion damage on metal } \\
\text { roofs, especially if freshly } \\
\text { painted }\end{array}$ & $\begin{array}{l}\text { Corrosion damage on } \\
\text { metal roofs, especially if } \\
\text { freshly painted }\end{array}$ & $\begin{array}{l}\text { Corrosion damage on } \\
\text { metal roofs, especially if } \\
\text { freshly painted }\end{array}$ & $\begin{array}{l}\text { Corrosion damage to metal roofs; } \\
\text { loading damage potential for flat } \\
\text { roofed structures, moderate if dry } \\
\text { (high over } 300 \mathrm{~mm} \text { ), high if wet. }\end{array}$ \\
\hline Pitched-roofs $\left(>20^{\circ}\right)$ & $\begin{array}{l}\text { Corrosion damage on metal } \\
\text { roofs, especially if freshly } \\
\text { painted }\end{array}$ & $\begin{array}{l}\text { Corrosion damage on } \\
\text { metal roofs, especially if } \\
\text { freshly painted }\end{array}$ & $\begin{array}{l}\text { Corrosion damage on } \\
\text { metal roofs, especially if } \\
\text { freshly painted }\end{array}$ & $\begin{array}{l}\text { Corrosion damage to metal roofs, } \\
\text { low to moderate risk of load dama } \\
\text { depending on roof pitch. }\end{array}$ \\
\hline \multicolumn{5}{|l|}{ Building services } \\
\hline Air-conditioning & $\begin{array}{l}\text { Abrasion damage to moving } \\
\text { parts. }\end{array}$ & $\begin{array}{l}\text { Abrasion damage to } \\
\text { moving parts. }\end{array}$ & $\begin{array}{l}\text { Blockage, abrasion damage } \\
\text { to moving parts. }\end{array}$ & $\begin{array}{l}\text { Blockage, abrasion damage to } \\
\text { moving parts. }\end{array}$ \\
\hline Gutters & Blockage from reworked ash. & $\begin{array}{l}\text { Blockage from reworked } \\
\text { ash, load damage. }\end{array}$ & $\begin{array}{l}\text { Blockage from reworked } \\
\text { ash, load damage. }\end{array}$ & $\begin{array}{l}\text { Blockage from reworked ash, load } \\
\text { damage. }\end{array}$ \\
\hline \multicolumn{5}{|l|}{ Electricity Services } \\
\hline Power lines & $\mathrm{N} / \mathrm{A}$ & $\begin{array}{l}\text { Loading, tree breakages } \\
\text { onto lines }\end{array}$ & $\begin{array}{l}\text { Loading, tree breakages } \\
\text { onto lines }\end{array}$ & Loading, tree breakages onto lines \\
\hline Power line insulators & $\mathrm{N} / \mathrm{A}$ & $\begin{array}{l}\text { Short-circuiting (flashover), } \\
\text { low potential if ash is dry, } \\
\text { high if ash is wet. }\end{array}$ & $\begin{array}{l}\text { Short-circuiting (flashover), } \\
\text { low potential if ash is dry, } \\
\text { high if ash is wet. }\end{array}$ & $\begin{array}{l}\text { Short-circuiting (flashover), low } \\
\text { potential if ash is dry, high if ash } \\
\text { is wet. }\end{array}$ \\
\hline Substations & $\mathrm{N} / \mathrm{A}$ & $\begin{array}{l}\text { Short-circuiting (flashover), } \\
\text { low potential if ash is dry, } \\
\text { high if ash is wet. Abrasion } \\
\text { damage to moving parts. }\end{array}$ & $\begin{array}{l}\text { Short-circuiting (flashover), } \\
\text { low potential if ash is dry, } \\
\text { high if ash is wet. Abrasion } \\
\text { damage to moving parts. }\end{array}$ & $\begin{array}{l}\text { Short-circuiting (flashover), low } \\
\text { potential if ash is dry, high if ash is } \\
\text { wet. Abrasion damage to moving } \\
\text { parts. }\end{array}$ \\
\hline \multicolumn{5}{|l|}{ Civil Structures } \\
\hline Roads & $\mathrm{N} / \mathrm{A}$ & $\begin{array}{l}\text { Blockage, reduced traction } \\
\text { and visibility }\end{array}$ & $\begin{array}{l}\text { Blockage, reduced traction } \\
\text { and visibility }\end{array}$ & $\begin{array}{l}\text { Blockage, reduced traction and } \\
\text { visibility }\end{array}$ \\
\hline Rail & $\mathrm{N} / \mathrm{A}$ & $\begin{array}{l}\text { Reduced traction and } \\
\text { visibility, short-circuiting of } \\
\text { electric signals if ash is } \\
\text { wet. }\end{array}$ & $\begin{array}{l}\text { Reduced traction and } \\
\text { visibility, short-circuiting of } \\
\text { electric signals if ash is wet. }\end{array}$ & $\begin{array}{l}\text { Blockage, reduced traction and } \\
\text { visibility, short-circuiting of electric } \\
\text { signals if ash is wet. }\end{array}$ \\
\hline \multicolumn{5}{|l|}{ Wastewater } \\
\hline Sewage pumps & $\begin{array}{l}\text { Abrasion damage to moving } \\
\text { parts (depends on turbidity } \\
\text { of sewage) }\end{array}$ & $\begin{array}{l}\text { Abrasion damage to } \\
\text { moving parts (depends on } \\
\text { turbidity of sewage) }\end{array}$ & $\begin{array}{l}\text { Abrasion damage to } \\
\text { moving parts (depends on } \\
\text { turbidity of sewage) }\end{array}$ & $\begin{array}{l}\text { Abrasion damage to moving parts } \\
\text { (depends on turbidity of sewage) }\end{array}$ \\
\hline $\begin{array}{l}\text { Sewage treatment } \\
\text { plant }\end{array}$ & $\begin{array}{l}\text { Abrasion damage to moving } \\
\text { parts (depends on turbidity } \\
\text { of sewage) }\end{array}$ & $\begin{array}{l}\text { Abrasion damage to } \\
\text { moving parts (depends on } \\
\text { turbidity of sewage), } \\
\text { damage to pond oxidation } \\
\text { process. }\end{array}$ & $\begin{array}{l}\text { Abrasion damage to } \\
\text { moving parts (depends on } \\
\text { turbidity of sewage), } \\
\text { damage to pond oxidation } \\
\text { process. }\end{array}$ & $\begin{array}{l}\text { Abrasion damage to moving parts } \\
\text { (depends on turbidity of sewage), } \\
\text { damage to pond oxidation proces }\end{array}$ \\
\hline \multicolumn{5}{|l|}{ Water Supply Systems } \\
\hline River/Stream & $\begin{array}{l}\mathrm{pH} \text { and turbidity } \\
\text { contamination }\end{array}$ & $\begin{array}{l}\mathrm{pH} \text { and turbidity } \\
\text { contamination }\end{array}$ & $\begin{array}{l}\mathrm{pH} \text { and turbidity } \\
\text { contamination }\end{array}$ & $\mathrm{pH}$ and turbidity contamination \\
\hline Uncovered reservoir & Turbidity contamination & $\begin{array}{l}\text { pH and turbidity } \\
\text { contamination }\end{array}$ & $\begin{array}{l}\text { pH and turbidity } \\
\text { contamination }\end{array}$ & $\mathrm{pH}$ and turbidity contamination \\
\hline $\begin{array}{l}\text { Cover reservoir/ } \\
\text { ground water }\end{array}$ & $\mathrm{N} / \mathrm{A}$ & $\mathrm{N} / \mathrm{A}$ & $\mathrm{N} / \mathrm{A}$ & $\mathrm{N} / \mathrm{A}$ \\
\hline Roof-fed tank & $\begin{array}{l}\text { Chemical, pH and turbidity } \\
\text { contamination }\end{array}$ & $\begin{array}{l}\text { Chemical, pH and turbidity } \\
\text { contamination }\end{array}$ & $\begin{array}{l}\text { Chemical, pH and turbidity } \\
\text { contamination }\end{array}$ & $\begin{array}{l}\text { Chemical, pH and turbidity } \\
\text { contamination }\end{array}$ \\
\hline
\end{tabular}

Telecommunications 
Table 3 Volcanic ash-induced damage type matrix (source: Daly and Wilkie, 1999) (Continued)

\begin{tabular}{|c|c|c|c|c|}
\hline & & $\begin{array}{l}\text { Loading, tree breakage } \\
\text { onto lines }\end{array}$ & $\begin{array}{l}\text { Loading, tree breakage } \\
\text { onto lines }\end{array}$ & \\
\hline Microwave towers & N/A & $\begin{array}{l}\text { Corrosion of metal } \\
\text { surfaces. }\end{array}$ & Corrosion of metal surfaces. & $\begin{array}{l}\text { Corrosion of metal surfaces, } \\
\text { possible load damage. }\end{array}$ \\
\hline \multicolumn{5}{|l|}{$\begin{array}{l}\text { Exchange } \\
\text { equipment: }\end{array}$} \\
\hline $\begin{array}{l}\text { External air- } \\
\text { conditioning }\end{array}$ & $\begin{array}{l}\text { Short-circuiting (flashover) } \\
\text { of equipment, abrasion } \\
\text { damage to moving parts }\end{array}$ & $\begin{array}{l}\text { Short-circuiting (flashover) } \\
\text { of equipment, abrasion } \\
\text { damage to moving parts }\end{array}$ & $\begin{array}{l}\text { Short-circuiting (flashover) } \\
\text { of equipment, abrasion } \\
\text { damage to moving parts }\end{array}$ & $\begin{array}{l}\text { Short-circuiting (flashover) of } \\
\text { equipment, abrasion damage } \\
\text { to moving parts }\end{array}$ \\
\hline $\begin{array}{l}\text { Internal air- } \\
\text { conditioning }\end{array}$ & $\mathrm{N} / \mathrm{A}$ & $\mathrm{N} / \mathrm{A}$ & $\mathrm{N} / \mathrm{A}$ & N/A \\
\hline \multicolumn{5}{|l|}{ Specific infrastructure } \\
\hline Ports & $\begin{array}{l}\text { Potential corrosion and } \\
\text { abrasion damage to port } \\
\text { facilities }\end{array}$ & $\begin{array}{l}\text { Potential corrosion and } \\
\text { abrasion damage to port } \\
\text { facilities }\end{array}$ & $\begin{array}{l}\text { Potential corrosion and } \\
\text { abrasion damage to port } \\
\text { facilities }\end{array}$ & $\begin{array}{l}\text { Potential corrosion and abrasion } \\
\text { damage to port facilities }\end{array}$ \\
\hline $\begin{array}{l}\text { Airports - Air } \\
\text { transport }\end{array}$ & $\begin{array}{l}\text { Potential corrosion and } \\
\text { abrasion damage to aircraft } \\
\text { and airport } \\
\text { (communications) } \\
\text { installations }\end{array}$ & $\begin{array}{l}\text { Potential corrosion and } \\
\text { abrasion damage to } \\
\text { aircraft and airport } \\
\text { (communications) } \\
\text { installations }\end{array}$ & $\begin{array}{l}\text { Potential corrosion and } \\
\text { abrasion damage to aircraft } \\
\text { and airport } \\
\text { (communications) } \\
\text { installations }\end{array}$ & $\begin{array}{l}\text { Potential corrosion and abrasion } \\
\text { damage to aircraft and airport } \\
\text { (communications) installations, } \\
\text { loading damage potential for flat } \\
\text { roofed structures, moderate if dry } \\
\text { (high over } 300 \mathrm{~mm} \text { ), high if wet. }\end{array}$ \\
\hline
\end{tabular}

b) Roads are the most important transport sector in relation to other 'lifelines' and in terms of public use. Access to utilities to remove ash and/or protect them often requires the use of roads at the very time they are affected by ash falls. Despite their importance they have a low dependence on other 'lifelines'.

c) Fuel supplies are important for standby electricity generation, and road, rail and air transportation, but most utilities will have access to sufficient supplies after an ash fall. Supplies have a moderate to low dependence on other 'lifelines'.

d) Electricity supplies are important for the operation of many 'lifelines' and are vulnerable during and after ash falls. Back-up electricity may not necessarily be available after an ash fall. Electricity supplies have only a moderate dependence on other 'lifelines'.

e) Cellular communications have a high priority during the initial recovery period.

f) Telephone systems have a moderate importance to other 'lifelines' but are highly dependent on electricity supplies and air-conditioning.

g) Air-conditioning units are important to a few lifelines, notably telephones, and are dependent on electricity and water.

h) Water supplies are required by a few 'lifelines' but since supply systems are relatively robust in Auckland, short-term problems should be minimal. However, water supplies have a high dependence on other 'lifelines', notably electricity supplies. Increased demand may strain the system. i) Stormwater, sewerage, rail, gas supplies and air transport are not required by most 'lifelines' but are highly dependent on others.

The interdependence table (Figure 10) is limited in that it does not indicate the consequence of the failure of certain lifelines to society in general. Sewerage and storm water both have low priority factors but are highly vulnerable to ash falls and their failure will have major societal impacts. Buildings, whether they are residential, business, or critical facilities (hospitals, fire and police stations, civil defence facilities, schools etc.), are extremely vulnerable to disruptions of lifelines which provide the services that allow them to operate. Electricity is required for lighting, ventilation, boilers, water heating, refrigerators/freezers, kitchens, medical services, lifts and security. Water supply is required for the satisfactory operation of hot and cold water systems, fire hoses and sprinklers, kitchens and laboratories. Communication facilities are critical for the operation of emergency management organisations, and usually require continued electricity supply.

An assessment of the vulnerability of lifelines must therefore consider the physical vulnerability of the particular lifeline, its dependence on other lifelines, the flow-on effects that its disruption may have and the societal demands placed on that lifeline after an event. Failure to consider all these aspects is illustrated by major water shortages in Anchorage, Alaska following a light ash fall from the 1992 Mount Spurr eruption. A vulnerability assessment of the water supply system and subsequent contingency planning had failed to anticipate increased water 
Table 4 Volcanic ash-induced mitigation matrix (source: Daly and Wilkie, 1999)

\begin{tabular}{|c|c|c|c|}
\hline Structure & Before the event & During ashfall event & After the event \\
\hline \multicolumn{4}{|l|}{ Pipework } \\
\hline $\begin{array}{l}\text { Open systems } \\
\text { (ie stormwater) }\end{array}$ & $\begin{array}{l}\text { Increase awareness of potential } \\
\text { problems, develop contingency plans }\end{array}$ & $\begin{array}{l}\text { Monitor turbidity levels, where possible } \\
\text { limit ash entering systems }\end{array}$ & $\begin{array}{l}\text { Monitor turbidity levels, where possible limit } \\
\text { ash entering systems, remove ash from pipes. }\end{array}$ \\
\hline Closed systems & N/A & $\mathrm{N} / \mathrm{A}$ & $\mathrm{N} / \mathrm{A}$ \\
\hline Building structures & $\begin{array}{l}\text { Increase awareness of potential } \\
\text { problems, develop contingency plans }\end{array}$ & Close windows, doors and other openings & $\begin{array}{l}\text { Initiate ash removal procedures immediately, } \\
\text { prioritize efforts }\end{array}$ \\
\hline \multicolumn{4}{|l|}{ Building services } \\
\hline Air-conditioning & $\begin{array}{l}\text { Increase awareness of potential } \\
\text { problems, develop contingency plans }\end{array}$ & $\begin{array}{l}\text { Shut down and cover air-intakes, if still in } \\
\text { use monitor filters and clean or replace } \\
\text { when necessary }\end{array}$ & $\begin{array}{l}\text { Initiate ash removal procedures immediately, } \\
\text { prioritize efforts }\end{array}$ \\
\hline Gutters & $\begin{array}{l}\text { Increase awareness of potential } \\
\text { problems, develop contingency plans }\end{array}$ & $\mathrm{N} / \mathrm{A}$ & Remove ash to prevent loading damage \\
\hline Electricity services & $\begin{array}{l}\text { Increase awareness of potential } \\
\text { problems, develop contingency plans }\end{array}$ & & \\
\hline Power lines & $\begin{array}{l}\text { Cut back tree branches from above } \\
\text { lines }\end{array}$ & Monitor the situation carefully & $\begin{array}{l}\text { Initiate ash removal procedures immediately, } \\
\text { prioritize efforts }\end{array}$ \\
\hline $\begin{array}{l}\text { Power line and } \\
\text { substation insulators }\end{array}$ & $\begin{array}{l}\text { Increase awareness of potential } \\
\text { problems, develop contingency plans }\end{array}$ & Monitor the situation carefully & $\begin{array}{l}\text { Initiate ash removal procedures immediately, } \\
\text { prioritize efforts }\end{array}$ \\
\hline \multicolumn{4}{|l|}{ Civil structures } \\
\hline Roads and rail & $\begin{array}{l}\text { Increase awareness of potential } \\
\text { problems, develop contingency plans }\end{array}$ & $\begin{array}{l}\text { Monitor the situation carefully, limit } \\
\text { vehicle use }\end{array}$ & $\begin{array}{l}\text { Initiate ash removal procedures immediately, } \\
\text { prioritize efforts, enhance vehicle } \\
\text { maintenance. }\end{array}$ \\
\hline Wastewater & $\begin{array}{l}\text { Increase awareness of potential } \\
\text { problems, develop contingency plans }\end{array}$ & $\begin{array}{l}\text { Warn public against disposing of ash } \\
\text { in the stormwater system }\end{array}$ & $\begin{array}{l}\text { Warn public of disposing of ash in the } \\
\text { stormwater system. }\end{array}$ \\
\hline Sewage pumps & $\begin{array}{l}\text { Increase awareness of potential } \\
\text { problems, develop contingency plans }\end{array}$ & $\begin{array}{l}\text { Monitor turbidity levels in the sewage and } \\
\text { shut down if levels are high }\end{array}$ & $\begin{array}{l}\text { Monitor turbidity levels in the sewage and } \\
\text { shut down if levels are high. }\end{array}$ \\
\hline Sewage treatment plant & $\begin{array}{l}\text { Increase awareness of potential } \\
\text { problems, develop contingency plans }\end{array}$ & $\begin{array}{l}\text { Monitor turbidity levels in the sewage and } \\
\text { shut down if levels are high }\end{array}$ & $\begin{array}{l}\text { Monitor turbidity levels in the sewage and } \\
\text { shut down if levels are high. }\end{array}$ \\
\hline Water supply systems & $\begin{array}{l}\text { Increase awareness of potential } \\
\text { problems, develop contingency plans }\end{array}$ & $\begin{array}{l}\text { Cover reservoir ventilators, disconnect roof } \\
\text { fed supplies, monitor water quality }\end{array}$ & $\begin{array}{l}\text { Initiate water supply management } \\
\text { procedures, monitor water quality }\end{array}$ \\
\hline Telecommunications & $\begin{array}{l}\text { Increase awareness of potential } \\
\text { problems, develop contingency plans }\end{array}$ & & \\
\hline \multicolumn{4}{|l|}{ Exchange equipment: } \\
\hline $\begin{array}{l}\text { External air- } \\
\text { conditioning }\end{array}$ & Fit internal air-conditioning units & $\begin{array}{l}\text { Seal exchanges where possible, shut down if } \\
\text { required, monitor the situation carefully }\end{array}$ & $\begin{array}{l}\text { Initiate ash removal procedures immediately, } \\
\text { prioritize efforts }\end{array}$ \\
\hline $\begin{array}{l}\text { Microwave towers, } \\
\text { other equipment }\end{array}$ & N/A & Monitor the situation carefully & $\begin{array}{l}\text { Initiate ash removal procedures immediately, } \\
\text { prioritize efforts }\end{array}$ \\
\hline Specific infrastructure & & & \\
\hline Ports & $\begin{array}{l}\text { Increase awareness of potential } \\
\text { problems, develop contingency plans }\end{array}$ & $\begin{array}{l}\text { Shut down vulnerability equipment, monitor } \\
\text { the situation carefully }\end{array}$ & $\begin{array}{l}\text { Initiate ash removal procedures immediately, } \\
\text { prioritize efforts }\end{array}$ \\
\hline Airports - Air transport & $\begin{array}{l}\text { Increase awareness of potential } \\
\text { problems, develop contingency plans }\end{array}$ & Close airspace, shut down airports & $\begin{array}{l}\text { Initiate ash removal procedures immediately, } \\
\text { prioritize efforts }\end{array}$ \\
\hline
\end{tabular}




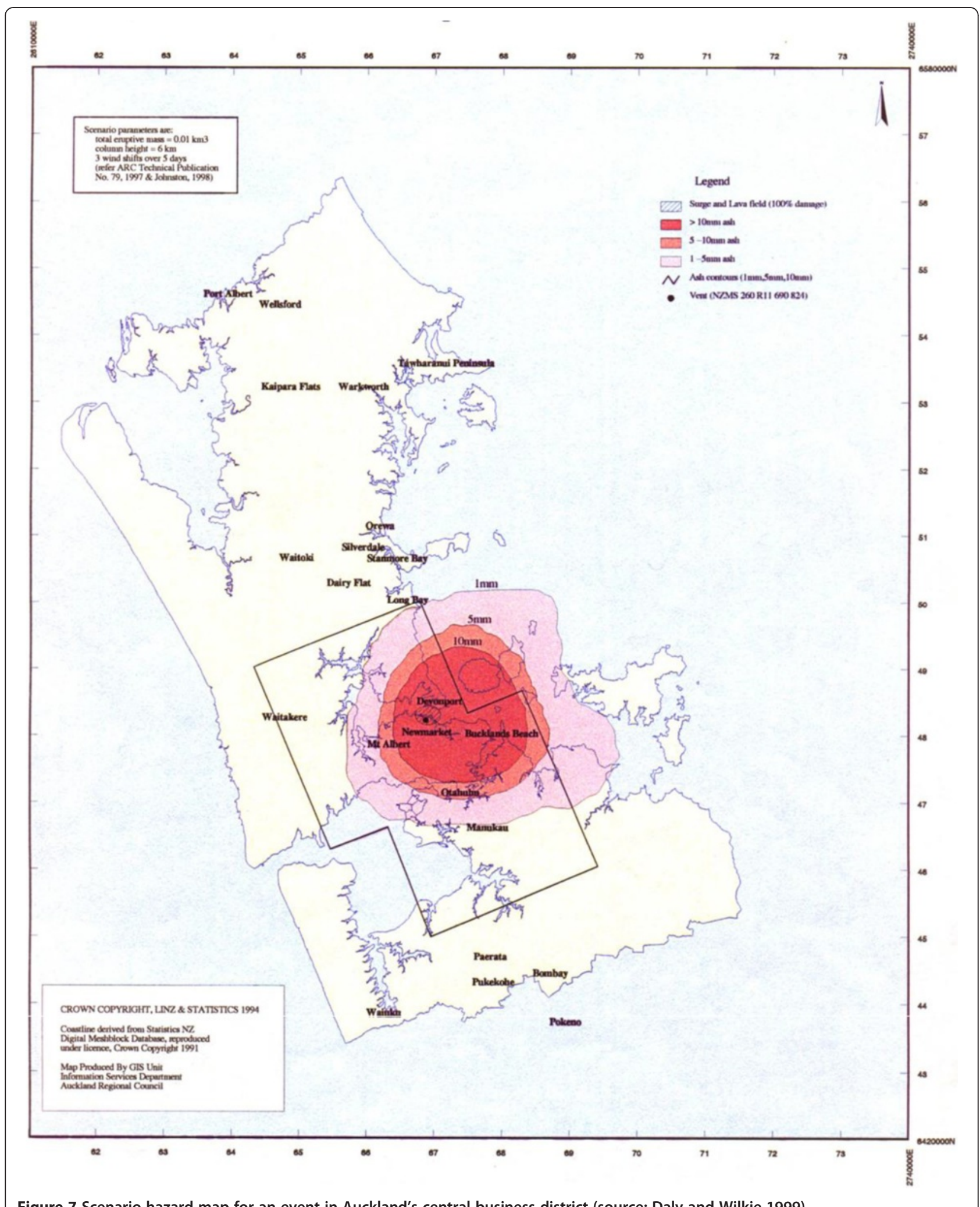

Figure 7 Scenario hazard map for an event in Auckland's central business district (source: Daly and Wilkie 1999). 


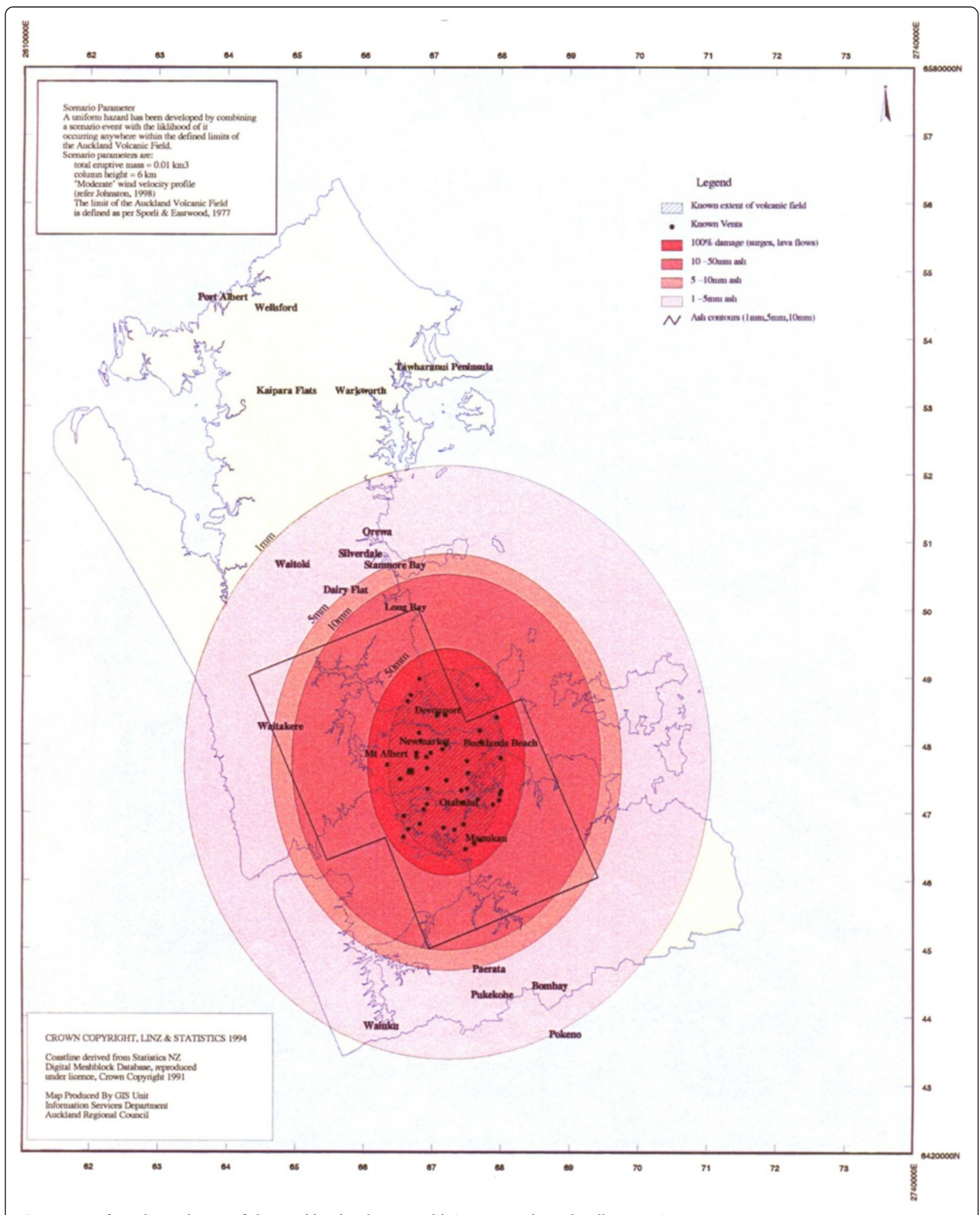

Figure 8 Uniform hazard map of the Auckland Volcanic Field. (source: Daly and Wilkie 1999). 


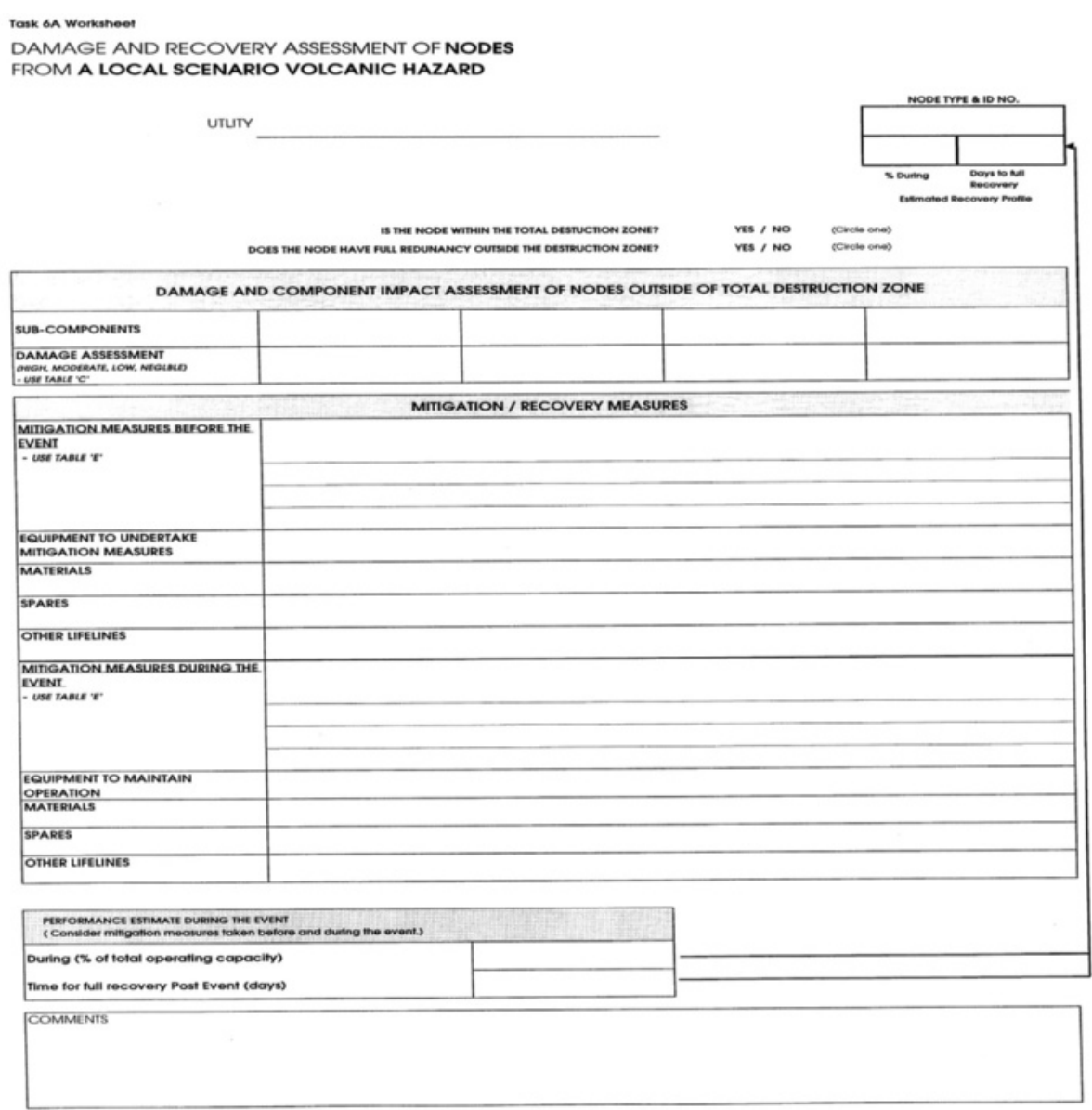

Figure 9 Example of a worksheet used to guide utilities through the damage, impact and recovery assessment process. Worksheets were filled in for node and network elements (separately) for each of the three scenario events (one local eruption and two distal eruptions - refer text for more information). (source: Daly and Wilkie 1999).

usage following such an event and appropriate measures were not taken once an ash fall warning was received (Johnston 1997b).

\section{Conclusions}

As well as identifying vulnerable elements and mitigation measures for individual utilities, the A.E.L.P. methodology allowed the effect on the entire network system to be assessed by considering a specific eruption scenario (among other hazards). The assessment focused on damage and the expected time taken to restore a certain level of service. This information formed the foundation of a regional response by lifeline utilities to such an event, and can be further developed to include essential non-utility services such as hospitals and emergency service centres.
The methodology used a mix of workshops and individual lifeline analyses to collect the information required. It was time consuming and may have been able to have been automated. However, the increase understanding about the network as a system gained through a more interactive process cannot be understated. Similarly, the relationships built up between the lifeline utility organisations enabled more robust and coordinated response planning arrangements to be put in place.

The A.E.L.P. methodology and supporting information was developed specifically for the lifeline utility sector, but in doing so provided the impetus for a refocused effort in understanding Auckland's volcanic risk. The eruption scenario descriptions, lifeline utility network information, damage and mitigation tables have remained in current use up until relatively recently when new studies underway are updating the information (e.g. AELP-2, 2014, 


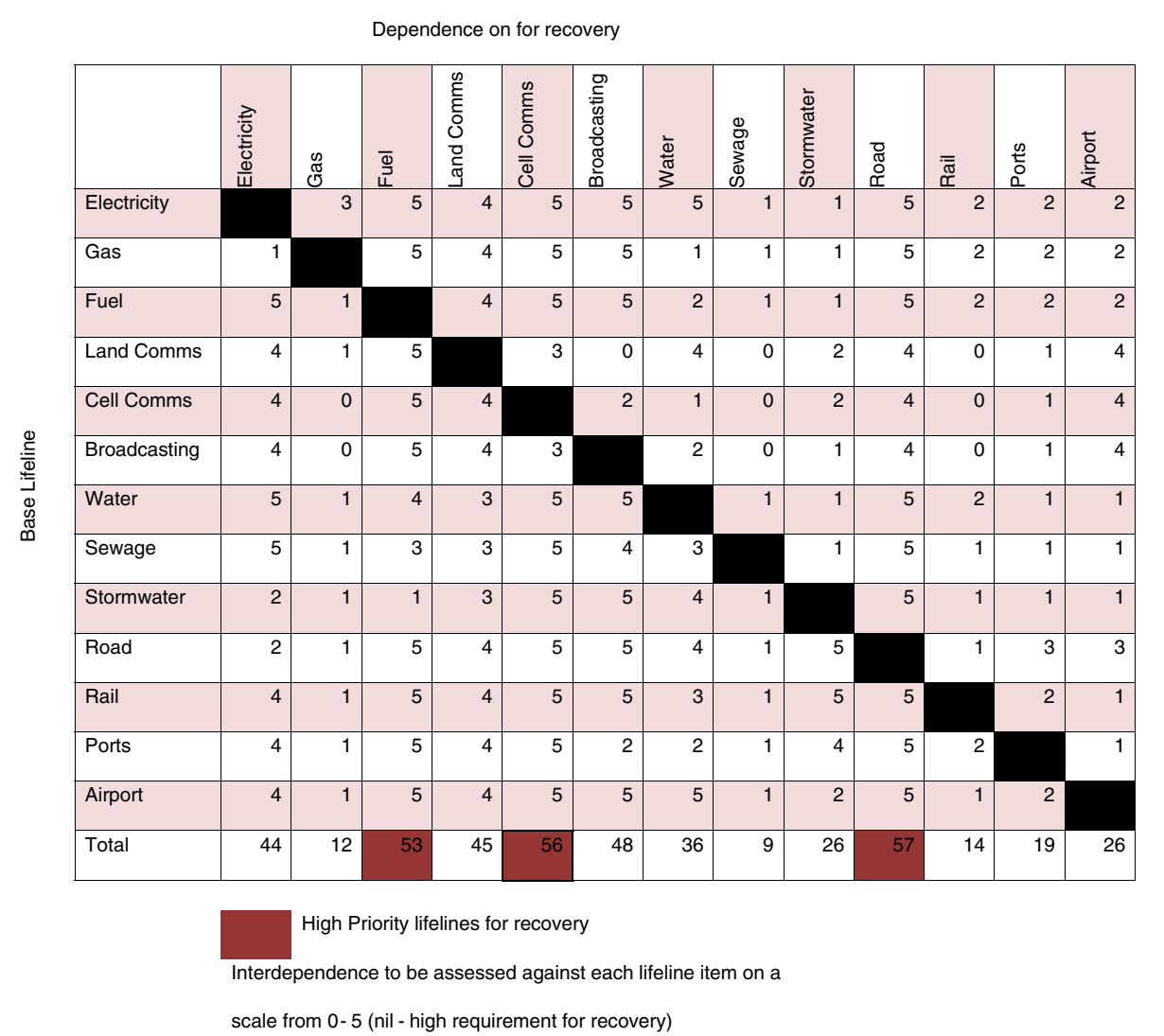

Figure 10 Interdependence recovery matrix for Auckland's lifeline utilities after the scenario eruption. (source: Daly and Wilkie 1999).

DEVORA, 2014). The damage zones developed formed the basis of evacuation planning for the region (Auckland Regional Council 2002) and the damage tables became the foundation for more quantitative fragility function research (e.g. Wilson et al., 2009; Wardman et al., 2012; Wilson et al., 2012; Wilson et al. 2014a) and information for lifelines on how to manage ash before, during and after ash fall (Wilson et al. 2014b).

The benefit to the many lifelines of participation in the A. E.L.P led to the establishment in 2000 of the Auckland Engineering Lifelines Group (A.E.L.G.) (renamed the Auckland Lifelines Group 2014) which is continuing work to reduce the vulnerability of Auckland's lifeline utility network to various natural hazard events.

The approach taken to develop the damage levels and time taken to restore levels of service after a large event may be useful for other cities around the world as increased emphasis is placed on reducing the vulnerability of their cities' infrastructure.

\section{Competing interests}

Both authors declare that they have no competing interests.

\section{Authors' contributions}

DJ developed the commissioned volcanic hazard analysis for the Auckland Volcanic Field for the A.E.L.P. and developed the damage, probability and mitigation tables in the paper. MD initiated and project managed the A.E.L.P. project. MD also led the development of the overall methodology for the A. E.L.P. including the hazard assessments, flowcharts and the worksheet. MD facilitated the workshops referred to in the paper which generated the interdependency data. All authors read and approved the final manuscript.

\section{Authors' information}

Michele Daly is a disaster risk management specialist at GNS Science in Lower Hutt, New Zealand. She currently leads a team of 20 social science, hazard, engineering and risk researchers at GNS Science who focus on practical strategies for reducing risk.

Dr. (Professor) David Johnston is Director of the Joint Centre for Disaster Research, a joint Massey University and GNS Science initiative focussed on graduate teaching and disaster research. Professor Johnston is currently Chair of the International Science Advisory Board (IAB) of the Integrated Research on Disaster Risk Scientific Committee (IRDR) Programme and an Honorary Professor at University College London.

\section{Acknowledgements}

We wish to thank Bianca Jensen (Massey University) and Maureen Coomer (GNS Science) for assistance with the tables and figures in this paper. The A. E.L.P. project was supported by the Auckland Regional Council and the many lifeline utilities of the Auckland Region. We would like to acknowledge the effort and commitment of these organisations to reducing risk in Auckland.

Received: 30 June 2014 Accepted: 3 February 2015

Published online: 19 February 2015

\section{References}

Auckland Council (2013) Auckland Volcanic Field Contingency Plan, April 2013. 54p. Auckland Lifelines Group (2014) Auckland Engineering Lifelines Project - Stage 2, v1.1., February 2014 [accessed 28 June 2014, www.aelg.org.nz) Auckland Regional Council (2002) Contingency Plan for the Auckland Volcanic Field. Technical Publication No. 165, January 2002. 74p 
Blong RJ (1984) Volcanic Hazards: A sourcebook on the effects of eruptions. Academic Press, Australia, p 424

Centre for Advanced Engineering (1997) Risks \& Realities: Vulnerability of Lifelines to Natural Hazards. Centre for Advanced Engineering, Canterbury University, New Zealand, p 350

Daly M, Wilkie D (1997) Auckland Engineering Lifelines Project Stage One Report: Part 1 (Hazard Information) and Part 2 (Network Utility Information). Auckland Regional Council, Technical Publication No.116, July. 1997, New Zealand, ISSN 11726415

Daly M, Wilkie D (1999) Auckland Engineering Lifelines Project Stage One Final Report. Auckland Regional Council, Technical Publication No.112, Nov. 1999, New Zealand, ISSN 11726415

DEVORA (2014) Determining Volcanic Risk in Auckland. http://www.naturalhazards. org.nz/NHRP/Hazard-themes/Geological-Hazards/Nolcano/DEVORADetermining-Volcanic-Risk-in-Auckland (as at June 2014)

Hopkins DC, Lumsden JL, Norton JA (1993) Lifelines in earthquakes: a case study based on Wellington. Bulletin of the New Zealand National Society for Earthquake Engineering 26(2):208-221

Johnston DM (1997a) The physical and social impacts of past and future volcanic eruptions in New Zealand. Unpublished Ph.D. thesis, Massey University, Palmerston North, New Zealand

Johnston, DM (1997b) The impact of recent falls of volcanic ash on public utilities in two communities in the United States of America. Institute of Geological \& Nuclear Sciences science report 97/5. 21 p

Johnston DM, Alloway BV, Smith IEM (1997a) Auckland Volcanic Impact Assessment - Distant Eruption Scenarios. Auckland Engineering Lifelines Project - Stage One Report, p. 171-192

Johnston DM, Nairn IA, Thordarson T, Daly M (1997b) Volcanic Impacts Assessment for the Auckland Volcanic Field. ARC Environment Division, Technical Publication Number 79

Lindsay JM, Leonard GS, Smid ER, Hayward B (2011) Age of the Auckland Volcanic Field: A review of existing data. New Zealand Journal of Geology and Geophysics 54(4):379-401, doi: 10.1080/00288306.2011.595805

Magill C (2002) Ashes to Ashes - Volcanic Risk in Auckland. Risk Frontiers Seminar Series 2(1):2, September 2002

Sandri L, Jolly G, Lindsay J, Howe T, Marzocchi W (2012) Combining long- and short-term probabilistic volcanic hazard assessment with cost-benefit analysis to support decision making in a volcanic crisis from the Auckland Volcanic Field, New Zealand. Bulletin of Volcanology 74(3):705-723

Smith IEM, Allen SR (1993) Volcanic hazards at the Auckland Volcanic Field, vol 5 Ministry of Civil Defence Volcanic Hazards Information, New Zealand, p 34

Wardman JB, Wilson TM, Bodger PS, Cole JW, Johnston DM (2012) Investigating the electrical conductivity of volcanic ash and its effect on $\mathrm{HV}$ power systems. Physics and Chemistry of the Earth, Parts A/B/C 45-46:128-145

Wilkie D, Daly MC (1998) Auckland Engineering Lifelines Project: assessing seismic risk. In: New Zealand National Society for Earthquake Engineering Technical Conference and AGM, Wairakei Resort, Taupo, Friday/Sunday 27-29 March 1998. New Zealand National Society for Earthquake Engineering, Lower Hutt, pp 130-136

Wilson CJN, Houghton BF, McWilliams MO, Lanphere MA, Weaver SD, Briggs RM (1995) Volcanic and structural evolution of Taupo Volcanic Zone, New Zealand: a review. Journal of Volcanology and Geothermal Research 68:1-28

Wilson TM, Daly M, Johnston D (2009) Review of Impacts of Volcanic Ash on Electricity Distribution Systems, Broadcasting and Communication Networks. Auckland Regional Council Technical Report No. 51, April 2009

Wilson TM, Stewart C, Sword-Daniels V, Leonard GS, Johnston DM, Cole JW, Wardman J, Wilson G, Barnard ST (2012) Volcanic ash impacts on critical infrastructure. Physics and Chemistry of the Earth, Parts A/B/C 45-46:5-23

Wilson G, Wilson TM, Deligne NI, Cole JC (2014a) Volcanic hazard impacts to critical infrastructure: A review. Journal of Volcanology and Geothermal Research 286:148-182

Wilson TM, Stewart C, Wardman JB, Wilson G, Johnston DM, Hill D, Hampton SJ, Villemure M, McBride S, Leonard GS, Daly MC, Delinge NI, and Roberts L (2014b) Volcanic ashfall preparedness poster series: a collaborative process for reducing the vulnerability of critical infrastructure. J Appl Volcanology 3(1): 1-25

\section{Submit your manuscript to a SpringerOpen ${ }^{\odot}$ journal and benefit from:}

- Convenient online submission

- Rigorous peer review

- Immediate publication on acceptance

- Open access: articles freely available online

- High visibility within the field

- Retaining the copyright to your article

Submit your next manuscript at $>$ springeropen.com 